\title{
PENGEMBANGAN SIKAP PROFESIONALISME GURU MELALUI KINERJA GURU PADA SATUAN PENDIDIKAN MTS NEGERI 1 SERANG
}

\author{
AEP SAEPUL ANWAR \\ Universitas Islam Negeri Sultan Maulana Hasanuddin Banten \\ aep.saepul.anwar@uinbanten.ac.id
}

FATKHUL MUBIN

Sekolah Tinggi Agama Islam (STAI) Alhikmah Jakarta

Fatkhulmubin90@gmail.com

\begin{abstract}
ABSTRAK
Tulisan ini bertujuan untuk mengetahui bagaimana pengembangan sikap profesionalisme guru melalui kinerja guru pada satuan pendidikan MTs Negeri 1 Serang. Penelitian ini adalah penelitian lapangan (filed research) yang bersifat deskriptif kualitatif, dengan tujuan yang akan dicapai peneliti adalah suatu gambaran secara faktual dengan pengumpulan data yang digunakan adalah observasi, wawancara, dan dokumentasi yang diperoleh langsung di lapangan. Adapun hasil penelitian tentang pengembangan sikap profesionalisme guru melalui kinerja guru pada satuan pendidikan MTs Negeri 1 Serang dilakukan dengan beberapa program dan upaya yaitu melakukan pendidikan dan pelatihan dengan melaksanakan musyawarah guru mata pelajaran (MGMP), Pendidikan dan pelatihan di tempat kerja, pelatihan jarak jauh, Kelompok Kerja Madrasah (KKM), penyusunan buku ajar dan LKS serta lainnya yang dapat menunjang pada peningkatan profesionalitas guru. Berdasarkan program di atas upaya yang dilakukan dalam meningkatkan kinerja guru terdapat beberapa program antara lain: Pertama; Program peningkatan kualifikasi pendidikan guru; Kedua; Program penyetaraan dan sertifikasi; Ketiga; Program pelatihan integritas berbasis kompetensi; Keempat; Program supervisi pendidikan; Kelima; Program pemberdayaan MGMP (Musyawarah Guru Mata Pelajaran); Keenam; Melakukan penelitian. Akhir dari penelitian ini bahwa pengembangan sikap profesionalisme guru melalui kinerja guru dilakukan di sekolah sendiri dengan memperhatikan kelemahan dari guru untuk saling menjadi bahan introspeksi guna perbaikan di masa yang akan datang. Akan tetapi pengembangan sikap profesionalisme guru di MTs Negeri 1 Serang dilakukan belum optimal melainkan masih membutuhkan bimbingan serta arahan guna tercapainya program tersebut dari stakeholder terkait baik pemerintah maupun pemerhati Pendidikan.
\end{abstract}

Kata Kunci: Pengembangan Sikap, Profesionalisme Guru, Kinerja Guru

\begin{abstract}
This paper aims to find out how to develop the attitude of professionalism of teachers through teacher performance in the MTs Negeri 1 Serang education unit. This research is a descriptive qualitative research, with the objective to be achieved by the researcher is a factual description by collecting data used is observation, interviews, and documentation obtained directly in the field. The results of research on the development of teacher professionalism through teacher performance in the education unit of MTs Negeri 1 Serang were carried out with several programs and efforts, namely conducting education and
\end{abstract}


training by carrying out subject teacher deliberations (MGMP), education and training in the workplace, distance training, Madrasah Working Group (KKM), the preparation of textbooks and worksheets and others that can support the improvement of teacher professionalism. Based on the above program efforts made in improving teacher performance there are several programs including: First; Teacher education qualification retention program, Second; Equalization and certification program, Third; Competency-based integrity training program, Fourth; Educational supervision program, Fifth; MGMP (Subject Teachers' Meeting) Empowerment Program, Sixth; Conduct research. The end of this research is that the development of teacher professionalism through teacher performance is carried out in the school itself by paying attention to the weaknesses of teachers to mutually become material for mutual reflection for future improvement. However, the development of teacher professionalism in MTs 1 Serang is not yet optimal but it still needs guidance and direction for the achievement of the program from relevant stakeholders both the government and education observers.

Keywords: Development of Attitude, Teacher Professionalism, Teacher Performance 


\section{A. PENDAHULUAN}

Berbicara tentang mutu pendidikan di Indonesia tidak akan pernah ada batasannya, hal ini tidak terlepas dari peranan berbagai pihak yang ikut serta bertanggung jawab dalam meningkatkan mutu pendidikan, ${ }^{1}$ salah satunya adalah peran tenaga kependidikan. Oemar Hamalik menjelaskan tenaga kependidikan merupakan suatu komponen yang amat penting dalam pelaksanaan pendidikan, yang bertugas menyelenggarakan kegiatan mengajar, melatih, meneliti, mengembangkan, mengelola dan memberikan pelayanan teknis dalam bidang kependidikan. $^{2}$

Dalam Undang-Undang Sistem Pendidikan Nasional Nomor 20 tahun 2003, Bab I pasal 1 ayat (5) menyebutkan bahwa: "tenaga kependidikan itu adalah anggota masyarakat yang mengabdikan diri dan diangkat untuk menunjang penyelenggaraan pendidikan", kemudian ayat (6) menyatakan bahwa "pendidik adalah tenaga kependidikan yang berkualifikasi sebagai guru, dosen, konselor, pamong belajar, widyaiswara, tutor, instruktur, fasilitator, dan sebutan lain yang sesuai dengan kekhususannya serta berpartisipasi dalam menyelenggarakan pendidikan". Pasal 39 ayat (2) menyebutkan bahwa "pendidik merupakan tenaga profesional yang bertugas merencanakan, dan melaksanakan proses pembelajaran, menilai hasil pembelajaran, melakukan pembimbingan dan pelatihan, serta melakukan penelitian dan pengabdian kepada masyarakat, terutama bagi pendidik pada perguruan tinggi".

Dari batasan tersebut terdapat aspek utama yang ditentukan adalah kualitas guru atau tenaga pendidik. Hal ini disebabkan guru merupakan titik sentral dalam pembaharuan dan peningkatan mutu pendidikan, dengan kata lain salah satu persyaratan penting bagi peningkatan mutu pendidikan adalah apabila pelaksanaan proses belajar mengajar dilakukan oleh pendidik-pendidik yang dapat diandalkan keprofesionalannya.

Guru sebagai pendidik profesional ${ }^{3}$ mempunyai citra yang baik di masyarakat apabila dapat menunjukkan kepada masyarakat bahwa ia layak menjadi panutan atau teladan masyarakat sekelilingnya. Masyarakat terutama akan melihat

${ }^{1}$ Mutu dalam pendidikan bukanlah barang akan tetapi layanan, di mana mutu harus dapat memenuhi kebutuhan, harapan dan keinginan semua pihak/pemakai dengan fokus utamanya terletak pada peserta didik (leaners). Mutu pendidikan berkembang seirama dengan tuntutan kebutuhan hasil pendidikan (output) yang berkaitan dengan kemajuan ilmu dan teknologi yang melekat pada wujud pengembangan kualitas sumber daya manusia. Sofan Amri, Peningkatan Mutu Pendidikan Sekolah Dasar dan Menengah dalam Teori Konsep dan Analisis (Jakarta: Prestasi Pustaka, 2013), 18.

2 Oemar Hamalik, Perencanaan Pengajaran Berdasarkan Pendekatan Sistem (Yogyakarta: Andi Offset, 2003), 9.

${ }^{3}$ Berdasarkan Peraturan Pemerintah. No 19 tahun 2005, pasal 28 ayat 1 menerangkan bahwa seorang pendidik harus memiliki kualifikasi akademik dan kompetensi sebagai agen pembelajaran, sehat jasmani dan rohani serta memiliki kemampuan untuk mewujudkan tujuan pendidikan nasional. Guru yang memiliki kualifikasi akademik adalah seorang tenaga kependidikan yang memiliki pengetahuan kependidikan dan keterampilan-keterampilan mengelola kelas dan menciptakan proses belajar mengajar yang menyenangkan. 
bagaimana sikap dan perbuatan guru itu sehari-hari, apakah memang ada yang patut diteladani atau tidak. Walaupun segala prilaku guru selalu diperhatikan masyarakat tetapi yang harus diperhatikan adalah sikap guru yang berkaitan dengan profesinya.

Trianto menjelaskan guru merupakan profesi/jabatan yang memerlukan keahlian khusus, hendaknya mampu memikul dan melaksanakan tanggungjawab terhadap peserta didik, orang tua,masyarakat, bangsa, Negara bahkan agama yang berkaitan dengan proses pendidikan bagi generasi penerus bangsa menuju gerbang pencerdasan dalam melepaskan diri dari belenggu kebodohan. Betapa berat tugas dan kewajiban yang harus diemban oleh pendidik dan tenaga kependidikan ini, sehingga menuntut profesionalitas tinggi dalam kinerjanya. Melalui kompetensi profesional, pendidik dan tenaga kependidikan harus mampu mewujudkan pengembangan profesi dalam rangka pengamalan ilmu pengetahuan, teknologi dan keterampilan untuk peningkatan mutu bagi proses belajar mengajar dan profesionalisme. $^{4}$

Kedudukan guru sebagai tenaga profesional mempunyai visi terwujudnya penyelenggaraan pembelajaran sesuai dengan prinsip profesionalisme untuk memenuhi hak yang sama bagi setiap warga Negara dalam memperoleh pendidikan yang bermutu. Kedudukan guru sebagai agen pembelajaran berkaitan dengan peran guru dalam pembelajaran, antara lain sebagai fasilitator, motivator, pemacu, perekayasaan pembelajaran, dan pemberi inspirasi belajar bagi peserta didik. peran tersebut perlu adanya pengembangan sikap profesional guru dalam meningkatkan kinerja seiring dengan perubahan dan tuntutan yang muncul terhadap dunia pendidikan dewasa ini.

Sementara profesionalisme guru dianggap berperan penting dalam membantu perkembangan peserta didik untuk mewujudkan tujuan hidupnya secara optimal. Karena hanya guru yang profesional, ia mampu menjalankan tugas dan fungsinya secara maksimal dalam membina akhlak mulia peserta didik. Suatu keniscayaan akan muncul karena manusia adalah makhluk lemah dan tidak berdaya, yang dalam perkembangannya senantiasa membutuhkan orang lain, demikian pula dengan peserta didik. Peserta didik membutuhkan peran orang lain, dalam hal ini adalah guru yang dapat membina, membimbing, dan mengarahkan, sehingga peserta didik mendapatkan pengetahuan sebagai pedoman hidupnya. ${ }^{5}$

Profesionalisme guru juga yang merupakan kondisi, arah, nilai, tujuan dan kualitas suatu keahlian dan kewenangan dalam bidang pendidikan dan pengajaran yang berkaitan dengan pekerjaan seseorang yang menjadi mata pencaharian. Namun kenyataan di lapangan sudah semakin sulit mendapatguru yang memenuhi

4 Trianto, Pengantar Penelitian Pendidikan bagi Pengembangan Profesi Pendidikan dan Tenaga Kependidikan (Jakarta: Kencana, 2011), IX.

${ }^{5}$ E. Mulyasa, Standar Kompetensi dan Sertifikasi Guru (Bandung: Remaja Rosdakarya, 2012), $35-$ 36. 
kualifikasi profesional. ${ }^{6}$ Oleh sebab itu perlu adanya upaya mengembangkan profesionalisme guru, salah satunya adalah dengan adanya sertifikasi guru. Sertifikasi guru merupakan salah satu cara dalam dunia pendidikan untuk meningkatkan kualitas dan profesionalitas seorang guru, sehingga ke depannya semua guru harus memiliki sertifikat sebagai lisensi atau ijin mengajar. Dengan demikian, upaya pembentukan guru yang profesional di Indonesia segera menjadi kenyataan seperti yang diharapkan.

Berdasarkan uraian diatas dengan memperhatikan bahwa kondusifitas yang dimiliki MTs Negeri 1 Serang merupakan salah satu faktor yang amat penting dalam melaksanakan pembangunan sekolah secara efektif terutama dalam melaksanakan standar proses guru senantiasa memberikan keteladanan, membangun kemauan dan mengembangkan potensi dan kreativitas dalam proses pembelajaran. Sesuai dengan Peraturan Pemerintah Nomor 19 tahun 2005 tentang standar nasional pendidikan, bahwa standar proses berkaitan dengan pelaksanaan pembelajaran pada satuan pendidikan untuk mencapai kompetensi lulusan. Sedangkan untuk standar tenaga pendidik dan kependidikan dengan mengembangkan kompetensi pedagogik, kepribadian, sosial dan profesional sejalan dengan hal ini, maka pada MTs Negeri 1 Serang telah mengacu pada PP tersebut terutama dalam melaksanakan standar proses dan tenaga pendidik dan kependidikan sehingga dalam penulisan jurnal ini dapat mengangkat permasalahan yang dapat diungkap di MTs Negeri 1 Serang adalah bagaimana penerapan dan pengembangan sikap profesionalisme guru melalui kinerja guru.

\section{B. METODE}

Metode dalam penulisan jurnal ini menggunakan metode kualitatif dengan pendekatan studi lapangan (field research). Tujuan yang ingin dicapai dalam penelitian ini adalah suatu gambaran secara faktual, penelitian ini bersifat bersifat naturalistic, dimana peneliti akan menggambarkan dan melukiskan realita dan konkrit yang terjadi di lapangan. Penelitian yang dilakukan di MTs Negeri 1 Serang, yang diperlukan dalam penelitian ini, adalah semua data yang berkaitan dengan kondisi objektif MTs Negeri 1 Serang yang meliputi profil madrasah, program kerja, struktur organisasi, dan lainnya. Sumber data penelitian ini diperoleh melalui wawancara dengan kepala madrasah, wakil kepala madrasah bidang kurikulum, wakil kepala bidang humas dan informasi, dan sebagian guru sebagai data utama atau data primer. Sedangkan data sekunder hanyalah sebatas data tambahan jika diperlukan dalam penelitian ini, data ini diperoleh dari dokumen-dokumen resmi, buku harian, dan sebagainya atau catatan tentang adanya suatu peristiwa atau catatan yang jaraknya telah jauh dari sumber orisinal. ${ }^{7}$

${ }^{6}$ Suparno Eko Widodo, Manajemen Peengembangan Sumber Daya Manusia (Yogyakarta: Pustaka Belajar, 2015), 15.

${ }^{7}$ Moh. Nazir, Metode Penelitian (Jakarta: Ghalia Indo, 2009), 50. 
Data yang diperoleh dalam penelitian ini adalah secara langsung dari pihak yang berkaitan dan berbagai literatur lain yang relevan dengan pembahasan penelitian. Selanjutnya proses analisis data dimulai dengan menelaah seluruh data yang tersedia dari berbagai sumber, yaitu wawancara, pengamatan yang sudah dituliskan dalam catatan lapangan, dokumen, gambar, foto dan sebagainya. Kemudian data sudah terkumpul data perlu direduksi atau diolah mulai dari editing dan koding. Kemudian tahap akhir analisis data ialah mengadakan pemeriksaan keabsahan data. ${ }^{8}$

\section{HASIL DAN PEMBAHASAN}

\section{Pengertian Sikap Profesionalisme Guru}

Seperti yang telah diungkapkan oleh Soetjipto dan Kosasi bahwa dalam rangka meningkatkan mutu, baik mutu profesional, maupun mutu layanan, guru harus pula meningkatkan sikap profesionalnya. Ini berarti bahwa ketujuh sasaran penyikapan yang telah dibicarakan harus selalu dipupuk dan dikembangkan. Pengembangan sikap profesional ini dapat dilakukan, baik selagi dalam pendidikan prajabatan maupun setelah bertugas (dalam jabatan). ${ }^{9}$

Sikap Profesional keguruan adalah sikap seorang guru dalam menjalankan pekerjaannya yang mencakup keahlian, kemahiran dan kecakapan yang memenuhi standar mutu atau norma tertentu serta memerlukan pendidikan profesi keguruan. Profesionalisme guru sering dikaitkan dengan tiga faktor yang cukup penting, yaitu kompetensi guru, sertifikasi guru, dan tunjangan profesi guru. Ketiga faktor tersebut disinyalir berkaitan erat dengan maju mundurnya kualitas pendidikan di Indonesia.

Sebagai reaksi maka sikap selalu berhubugan dengan dua alternatif, yaitu senang (like) atau tidak senang (dislike), menurut dan melaksanakan atau menjauhi/menghindari sesuatu. Nana Sudjana sendiri menjelaskan profesional adalah pekerjaan atau kegiatan yang dilakukan oleh seseorang dan menjadi sumber penghasilan kehidupan yang memerlukan keahlian, kemahiran, atau kecakap. Pekerjaan yang bersifat profesional adalah pekerjaan yang hanya dapat dilakukan oleh mereka khusus dipersiapkan untuk itu dan bukan pekerjaan yang dilakukan oleh mereka karena tidak dapat memperoleh pekerjaan yang lain". ${ }^{10}$

Menurut para ahli profesionalisme menekankan kepada penguasaan ilmu pengetahuan atau kemampuan manajemen beserta strategi penerapannya. Maister sendiri mengemukakan bahwa profesionalisme bukan sekedar pengetahuan teknologi dana manajemen tatapi lebih merupakan sikap, pengembangan

\footnotetext{
${ }^{8}$ Moleong, Metodologi Penelitian Kualitatif (Bandung: PT. Remaja Rosdakarya, 1999), 190-191.

${ }^{9}$ Soetjipto, Profesi Keguruan (Jakarta: Rineka Cipta, 2009), 54.

${ }^{10}$ David Thomas Duli, "Pengembangan Sikap Profesional", Jurnal Universitas Nusa Cendana,
} 2016, 13. 
profesionalisme lebih dari seorang teknisi bukan hanya memiliki keterampilan yang tinggi tetapi memiliki suatu tingkah laku yang dipersyaratkan. ${ }^{11}$

Guru sebagai pendidikan profesional mempunyai citra yang baik dimasyarakat apabila dapat menunjukkan kepada masyarakat bahwa ia layak menjadi panutan atau teladan masyarakat sekelilingnya. Masyarakat terutama akan mepelihat bagaimana sikap dan perbuatan guru itu sehari-hari, apakah memang ada yang patut diteladani atau tidak. Walaupun segala prilaku guru selalu diperhatikan masyarakat tetapi harus diperhatikan adalah sikap guru yang berkaitan dengan profesinya.

Selanjutnya, dijelaskan pula menurut Arifin bahwa guru Indonesia yang profesional memiliki beberapa yang dipersyaratkan yaitu:

a) Dasar ilmu yang kuat sebagai pengejawantahan terhadap masyarakat teknologi dan masyarakat ilmu pengetahuan di abad 21.

b) Penguasaan kiat-kiat profesi berdasarkan riset dan praksis pendidikan yaitu ilmu pendidikan sebagai ilmu praksis bukan hanya merupakan konsepkonsep belaka. Pendidikan merupakan proses yang terjadi dilapangan dan bersifat ilmiah, serta riset pendidikan hendaknya diarahkan pada praksis pendidikan masyarakat indonesia.

c) Pengembangan kemampuan profesioanl berkesinambungan profesi guru merupakan profesi yang berkembang terus menerus dan berkesinambungan antara LPTK dengan praktek pendidikan Kekerdilan profesi guru dan ilmu pendidikan disebabkan terputusnya program pre-servie dan in-service karena pertimbangan birokratis yang kaku atau manajemen pendidikan yang lemah. ${ }^{12}$

Profesi adalah suatu pekerjaan yang dalam melaksanakan tugasnya memerlukan/menuntut keahlian (expertise), yang menggunakan teknik ilmiah serta dedikasi yang tinggi. Profesional adalah pekerjaan atau kegiatan yang dilakukan oleh seorang dan menjadi sumber penghasiloan kehidupan yang memerlukan keahlian, kemahiran, dan kecakapan yang memenuhi standar mutu atau norma tertentu serta memerlukan pendidikan profesi. ${ }^{13}$ Guru sebagai pendidik professional dituntut untuk selalu menjadi teladan bagi masyarakat disekelilingnya.

Sikap profesional keguruan adalah sikap seorang guru dalam menjalankan pekerjaannya yang mencakup keahlian, kemahiran dan kecakapan yang memenuhi standar mutu atau norma tertentu serta memerlukan pendidikan profesi keguruan.

a) Ciri-ciri Guru Profesional

1) memiliki skill/keahlian dalam mendidik atau mengajar

2) memiliki kemampuan intelektual yang memadai

3) kemampuan memahami visi dan misi pendidikan

4) keahlian mentransfer ilmu pengetahuan atau metodologi pembelajaran

5) memahami konsep perkembangan anak/psikologi perkembangan

6) kemampuan mengorganisir dan problem solving

\footnotetext{
11 Soetjipto, Profesi Keguruan, 54.

12 Ramayulis, Profesi dan Etika Keguruan (Jakarta: Kalam Mulia, 2012), 30.

${ }^{13}$ Lihat kembali Undang-undang Nomor 14 Tahun 2005 tentang Guru dan Dosen Pasal 14
} 
7) kreatif dan memiliki seni dalam mendidik

\section{b) Personaliti Guru}

Profesi guru sangat identik dengan peran mendidik seperti membimbing, membina, mengasuh ataupun mengajar. Ibarat sebuah contoh lukisan yang akan ditiru anak didiknya. Baik buruk hasil lukisan tersebut tergantung dari contohnya. Guru otomatis menajdi teladan. Melihat peran tersebut, sudah menjadi kemutlakan bhawa guru harus memiliki integritas dan personaliti yang baik dan benar. Hal ini sangat mendasar, karena tugas guru bukan hanya mengajar (transfer knowledge) tetapi juga menanamkan nilai-nilai dasar dari bangun karakter atau akhlak anak.

c) Memposisikan Profesi Guru sebagai The High Class Profesi

Di Indonesia sudah menjadi realitas umum guru bukan menjadi profesi yang berkelas baik secara sosial maupun ekonomi. Hal yang basa, apabila menjadi Teller di sebuah Bank, lebih terlihat highclass dibandingkan guru. Jika ingin memposisikan profesi guru setara dengan profesi lainnya, mulai di blowup baha profesi guru strata atau derajat yang tinggi dan dihormati dalam masyarakat. Karena mengingat begitu fundamental peran guru bagi proses perubahan dan perbaikan di masyarakat.

d) Program Profesionalisme Guru

1) Pola rekruitmen yang berstandar dan kolektif

2) Pelatihan yang terpadu, berjenjang dan kesinambungan (Long Life Education)

3) Penyetaraan pendidikan dan membuat standarisasi minimum pendidikan

4) Pengembangan diri dan motivasi riset

5) Pengayaan kreativitas untuk menjadi guru karya (guru yang menjadi bisa)

e) Peran Manajemen Sekolah

1) Fasilitator program pelatihan dan pengembangan profesi

2) Menciptakan jenjang karier yang fair dan terbuka

3) Membangun manajemen dan sistem ketenagaan yang baku

4) Membangun sistem kesejahteraan guru berbasis prestasi

\section{Pengembangan Sikap Profesional Guru}

Untuk menjadi guru profesional ${ }^{14}$ adalah suatu keniscayaan. Namun demikian, profesi $i^{15}$ guru juga sangat lekat dengan peran psikologis, humannis bahkan identik

14 Profesionalisme dapat diartikan sebagai pandangan yang menganggap bidang pekerjaan sebagai suatu pengabdian melalui keahlian tertentu dan yang menganggap keahlian ini sebagai sesuatu yang harus diperbarui secara terus menerus dengan memanfaatkan kemajuan-kemajuan dalam ilmu pengetahuan. Abudin Nata Nata, Manajemen Pendidikan (Jakarta: Kencana Prenada Media Group, 2010), 155. Lihat juga Udin Syaefudin Saud, Pengembangan Profesi Guru (Bandung: Alfabeta, 2010), 7.

${ }^{15}$ Djam'an satori dalam Soetjipto menyatakan profesi adalah suatu jabatan atau pekerjaan yang menuntut keahlian (expertise) dari pada anggotanya", artinya, suatu profesi tidak bisa dilakukan oleh sembarang orang. Orang yang menjalankan suatu profesi harus mempunyai keahlian khusus bagi profesi tersebut. Lihat Soetjipto, Profesi Keguruan, h. 15. 
dengan citra kemanusiaan. Untuk mengembangkan sikap profesionalisme guru selalu mendapatkan perhatian secara universal, karena guru bukan hanya sebatas ikut serta mencerdaskan bangsa tapi berperan penting dalam sentral pendidikan karakter. Tugas mulia yang diemban seorang guru tersebut menjadi berat karena bukan saja guru harus mempersiapkan generasi muda sebagai penerus yang mampu bersaing namun juga unggul dari segi karakter. Mengembangkan sikap profesi guru bukan sesuatu yang mudah, maka diperlukan strategi yang tepat dalam upaya menciptakan iklim kondusif bagi pengembangan profesi guru. Situasi kondusif ini jelas amat diperlukan oleh tenaga pendidik untuk dapat mengembangkan diri sendiri ke arah profesionalisme guru.

Secara umum sikap professional seorang guru dapat dilihat dari faktor luar. Akan tetapi, hal tersebut belum mencerminkan seberapa baik potensi yang dimilikiguru sebagai seorang pendidik. Menurut PP No.74 Tahun 2008 pasal 1 ayat1 Tentang Guru menjelaskan "Guru adalah pendidika profesional dengan tugas utama mendidik, mengajar, membimbing, mengarahkan, melatih, menilai, dan mengevaluasi peserta didik pada pendidikan anak usia dini jalar pendidikan normal, pendidikan dasar, dan pendidikan menengah". Pengembangan sikap professional dalam rangka meningkatkan mutu, baik mutu professional maupun mutu layanan, guru juga harus meningkatkan sikap profesionalnya. Pengembangan sikap professional dapat dilakukan selagi dalam pendidikan prajabatan maupun selagi bertugas (dalam jabatan)

\section{Pengembangan Sikap Selama Pendidikan Pra-Jabatan.}

Dalam pendidikan pra-jabatan calon guru dalam berbagai pengetahuan, sikap, dan keterampilan yang diperlukan dalam pekerjaannya nanti. Karena tugasnya yang bersifat unik, guru selalu menjadi panutan bagi sisanya, dan bahkan bagi masyarakat sekelilingnya. Oleh karena itu, guru bersikap terhadap pekerjaan dan jabatannya selalu menjadi perhatian siswa dan masyarakat.

Pembentukan sikap yang baik tidak mungkin muncul begitu saja, tetapi harus dibina sejak calon guru memulai pendidikannya di lembaga pendidikan guru. Berbagai usaha, latihan, contoh-contoh, aplikasi penerapan ilmu, keterampilan, serta sikap profesional yang dirancang dan dilaksanakan selama calon guru berada dalam pendidikan pra-jabatan. Sering juga pembentukan sikap tertentu terjadi sebagai hasil sampingan (by product) dari pengetahuan yang diperoleh calon guru. Sikap teliti dan disiplin, misalnya dapat terbentuk sebagai hasil sampingan dari hasil belajar matematika yang benar, karena belajar matematika selalu menuntut ketelitian dan kedisiplinan penggunaan aturan dan prosedur yang telah ditentukan. Sementara itu tentu saja pembentukan sikap dapat diberikan dengan memberikan pengetahuan, pemahaman, dan penghayatan khusus yang direncanakan, sebagaimana halnya mempelajari pedoman penghayatan dan pengamalan pancasila (P4) yang diberikan kepada seluruh siswa sejak dari sekolah dasar sampai perguruan tinggi. 


\section{Pengembangan Sikap Selama dalam Jabatan}

Pengembangan sikap profesional tidak berhenti apabila calon guru selesai mendapatkan pendidikan pra-jabatan. Banyak usaha yang dilakukan dalam rangka peningkatan sikap profesional keguruan dalam masa pengabdiannya sebagai guru. Seperti telah disebut, peningkatan ini dapat dilakukan dengan cara formal melalui kegiatan mengikuti penataran loka karya, seminar, atau informal melalui media massa televisi, radio, koran, dan majalah maupun publikasi lainnya. Kegiatan ini selain dapat meningkatkan pengetahuan dan keterampilan, sekaligus dapat juga meningkatkan sikap profesional keguruan.

\section{Pengertian Kinerja Profesional Guru}

Tingkat keberhasilan guru dalam menyelesaikan pekerjaannya disebut dengan istilah "level of performance" atau level kinerja. Kinerja bukan merupakan karakteristik individu, seperti bakat atau kemampuan, tetapi merupakan perwujudan dari bakat atau kemampuan itu sendiri. ${ }^{16}$ Kinerja merupakan perwujudan dari kemampuan dalam bentuk karya nyata. Kinerja merupakan hasil kerja yang dicapai guru di sekolah dalam rangka mencapai tujuan sekolah. Kinerja guru Nampak dari tanggungjawabnya dalam menjalankan amanah, profesi yang diembannya, serta moral yang dimilikinya. Hal tersebut akan tercermin dari kepatuhan, kepatutan, komitmen dan loyalitasnya dalam mengembangkan potensi peserta didik serta memajukan sekolah. Guru yang memiliki level kinerja tinggi merupakan guru yang memiliki produktivitas kerja sama dengan/di atas standar yang ditentukan, begitupun sebaliknya, guru yang memiliki level kinerja rendah, maka guru tersebut merupakan guru yang tidak produktif.

Kinerja guru merupakan kemampuan guru dalam menunjukkan kecakapan atau kompetensi yang dimilikinya dalam dunia kerja yang sebenarnya. Dunia kerja guru yang sebenarnya adalah pembelajaran siswa dalam kegiatan pembelajaran dikelas. Kinerja guru adalah segala hasil dari usaha guru dalam mengantarkan proses pembelajaran untuk mencapai tujuan pendidikan, yang meliputi seluruh kegiatan yang menyangkut tugasnya sebagai guru. Tugas profesional seorang guru mencakup kegiatan mendidik, mengajar, membimbing, mengarahkan, melatih, menilai dan mengevaluasi peserta didik.

Dengan demikian, kinerja guru merupakan hasil kerja yang dicapai oleh seorang guru dalam melaksanakan tugas mendidik, mengajar, membimbing, mengarahkan, melatih, menilai, dan mengevaluasi peserta didik. Kinerja seorang guru dapat dilihat dari prestasi yang diperoleh oleh seorang guru, bagaimana seorang guru dalam melaksanakan proses pembelajaran dan mengevaluasi hasil pembelajaran serta memberikan tindak lanjut dari evaluasi pembelajaran, dan hasil kerja yang diperoleh oleh seorang guru.

\footnotetext{
${ }^{16}$ Donni Juni Priansa, Kineja dan Profesionalisme Guru (Bandung: Alfabeta, 2014), 79.
} 
Kinerja profesional guru merupakan suatu kegiatan yang dilakukan untuk melaksanakan, menyelesaikan tugas dan tanggung jawab sesuai dengan harapan dan tujuan yang telah ditetapkan dalam kegiatan pembelajaran di kelas dan pendidikan di sekolah. Kinerja diartikan sebagai prestasi, menunjukkan suatu kegiatan atau perbuatan dan melaksanakan tugas yang telah dibebankan. Pengertian kinerja disering diidentikkan dengan prestasi kerja. Karena ada persamaan antara kinerja dengan prestasi kerja.

Kinerja profesional terdiri dari dua kata, yaitu kinerja dan profesional. Istilah kinerja sering diidentikkan dengan istilah prestasi. Istilah kinerja atau prestasi merupakan pengalih bahasaan dari kata inggris "performance". Terdapat beberapa pengertian mengenai kinerja yaitu sebagai berikut:

1) Mangkunegara mendefinisikan kinerja adalah hasil kerja yang secara kualitas dan kuantitas yang dicapai oleh seorang pegawai dalam melaksanakan tugasnya sesuai dengan tanggung jawab yang diberikan kepadanya.

2) Sulistiyani dan Rosidah menyatakan kinerja seseorang merupakan kombinasi dari kemampuan, usaha, dan kesempatan yang dapat dinilai dari hasil kerjanya.

3) Bernandin dan Rusell mengemukakan kinerja adalah suatu hasil kerja yang dicapai seseorang dalam melaksanakan tugas-tugas yang dibebankan kepadanya yang didasarkan ataskecakapan, pengalaman, dan kesungguhan, serta waktu. ${ }^{17}$

Berdasarkan pendapat para ahli tersebut, definisi kerja sebagai hasil kerja yang dicapai oleh individu yang disesuaikan dengan peran atau tugas individu tersebut dalam suatu organisasi pada suatu periode tertentu, yang dihubungkan dengan suatu ukuran nilai atau standar tertentu dari organisasi dimana individu tersebut bekerja. Sedangkan profesional adalah seseorang yang hidup dengan mempraktekkan suatu keahlian pada pendidikan dan jenjang pendidikannya atau dengan terlibat dalam suatu kegiatan tertentu yang menurut keahlian yang dimilikinya yang merupakan jalan untuk mendapatkan hasil yang maksimal dari apa yang berupaya pekerjaannya. Dengan demikian, kinerja profesional merupakan hasil kerja yang dicapai oleh individu dengan mempraktekkan suatu keahlian pada pendidikan dan jenjang pendidikannya pada suatu periode tertentu, yang dihubungkan dengan suatu ukuran nilai atau standar tertentu dari organisasi dimana individu tersebut bekerja.

\section{Sasaran Sikap Profesional Guru}

Secara umum, sikap profesional seorang guru dapat dilihat dari faktor luar, akan tetapi, hal tersebut belum mencerminkan seberapa baik potensi yang dimiliki guru sebagai seorang tanpa pendidik. Menurut PP No.74 Tahun 2008 pasal 1.1 tentang Guru dan UU. No.14 Tahun 2005 pasal 1.1 Tentang guru dan Dosen, guru

17 Supardi, Kinerja Guru (Jakarta: PT Raja Grafindo Persada, 2013), 45. Lihat juga, Saihu, S. (2019). Pendidikan Pluralisme Agama: Kajian tentang Integrasi Budaya dan Agama dalam Menyelesaikan Konflik Sosial Kontemporer. Jurnal Indo-Islamika, 9(1), 67-90. 
adalah pendidik profesional dengan tugas utama mendidik, mengajar, membimbing, mengarahkan, melatih, menilai, dan mengevaluasi peserta didik pada pendidikan anak usia dini jalar pendidikan formal, pendidikan dasar, dan pendidikan menengah. Berikut ini yang dijadikan sasaran dengan profesi keguruan yaitu meliputi sikap profesional keguruan terhadap (1) peraturan perundang-undangan, (2) Organisasi Profesi, (3) Teman Sejawat, (4) Anak didik, (5) Tempat Kerja, (6) Pemimpin, dan (7) Pekerjaan. ${ }^{18}$

\section{Sikap Terhadap Peraturan Perundang-Undangan}

Kode etik guru Indonesia pada butir kesembilan bahwasanya:"Guru melaksanakan segala kebijakan pemerintah dalam bidang pendidikan" (PGRI, 1973). Kebijakan pendidikan di negara ini dipegang oleh pemerintah dalam hal ini oleh Departemen Pendidikan dan Kebudayaan yang mengeluarkan ketentuan-ketentuan dan peraturan-peraturan yang merupakan kebijakan yang akan dilaksanakan oleh aparatnya antara lain: pembangunan gedung-gedung pendidikan, pemerataan kesempatan belajar antara lain dengan melalui kewajiban belajar, peningkatan mutu pendidikan, pembinaan generasi muda dengan men-giatkan kekuatan karang taruna.

Guru merupakan unsur aparatur Negara dan abdi-Negara. Karena itu, guru mutlak perlu mengetahui kebijaksanaan pemerintah dalam bidang pendidikan, sehingga dapat melaksanakan ketentuan-ketentuan yang merupakan kebijaksanaan tersebut. Kebijaksanaan pemerintah dalam bidang pendidikan ialah segala peraturan peratutan baik yang dikeluarkan oleh Departemen Pendidikan dan Kebudayaan di Pusat maupun di daerah, maupun departemen lain dalam rangka pembinaan pendidikan di negara kita. Seperti peraturan tentang berlakunya kurikulum sekolah ternetu pembebasan uang Sumbangan Pembiayaan Pendidikan (SPP). Ketentuan tentang penerimaan murid baru penyelenggaraan evaluasi belajar tahap akhir (EBTA) dan lain sebagainya.

Kode etik guru Indonesia mengatur agar guru indonesia tetap melaksanakan ketentuan-ketentuan yang merupakan kebijaksanaan pemerintah dalam bidang pendidikan seperti yang tetuang dalam dasar kesembilan dari kode etik guru. Dasar ini menunjukkan bahwa guru Indonesia harus tunduk dan taat kepada pemerintah Indonesia dalam menjalankan tugas pengabdiannya, sehingga guru indonesia tidak mendapat pengaruh yang negative dari pihak luar, yang ingin memaksakan idenya melalui dunia pendidikan. Dengan demikian, setiap guru indonesia wajib tunduk dan taat kepada segala ketentuan-ketentuan pemerintah, baik yang dikeluarkan oleh Departemen Pendidikan dan kebudayaan, maupun departemen lain yang berwenang mengatur pendidikan.

\section{Sikap Terhadap Organisasi Profesi}

${ }^{18}$ Lihat Kembali Undang-undang RI Nomor 14 Tahun 2005 Pasal 1 Tentang guru dan Dosen, 
Guru secara bersama-sama memelihara dan meningkatkan mutu organisasi PGRI sebagai sarana perjuangan dan pengabdian. Sementara guru pada satuan madrasah sebagai payung organisasinya berada di bawah naungan Persatuan Guru Madrasah Indonesia (PGMI) dasar ini menunjukkan bahwa betapa pentingnya peranan organisasi profesi sebagai wadah dan sarana pengabdian.

PGRI dan PGMI sebagai organisasi profesi memerlukan pembinaan, agar lebih berdaya guna dan berhasil guna sebagai wadah usaha untuk membawakan misi dan menetapkan profesi guru. Keberhasilannya sangat bergantung kepada kesadaran para anggotanya, rasa tanggung jawab dan kewajiban para anggotanya. Organisasi PGRI dan PGMI adalah suatu sistem yang unsur pembentukannya adalah guru-guru. Oleh karena itu, guru harus bertindak sesuai dengan tujuan sistem. Ada hubungan timbal balik antara anggota profesi dengan organisasi, baik dalam melaksanakan kewajiban maupun dalam mendapatkan hak.

\section{Sikap Terhadap Teman Sejawat}

Dalam ayat kode etiki guru disebutkan bahwa guru memelihara hubungan seprofesi, semangat kekeluargaan, dan kesetiakawanan sosial. Ini berarti sebagai berikut: (a) Guru hendaknya menciptakan dan memelihara hubungan sesama guru dealam lingkungan kerjanya, (b) Guru hendaknya menciptakan dan memelihara semangat kekeluargaan dan kesetiakawanan sosial di dalam dan di luar lingkungan kerjanya.

Dalam hal ini ditunjukkan bahwa betapa pentingnya hubungan yang harmonis untuk menciptakan rasa persaudaraan yang kuat di antara sesama anggota profesi khususnya di lingkungan kerja yaitu sekolah, guru hendaknya menunjukkan suatu sikap yang ingin bekerja sama, menghargai, pengertian, dan rasa tanggung jawab kepada sesama personel sekolah. Sikap ini diharapkan akan memunculkan suatu rasa senasib sepenanggungan, menyadari kepentingan bersama, dan tidak mementingkan kepentingan sendiri dengan mengorbankan kepentingan orang lain, sehingga kemajuan sekolah pada khususnya dan kemajuan pendidikan pada umumnya dapat terlaksana. Sikap ini hendaknya juga dilaksanakan dalam pergaulan yang lebih luas yaitu sesama guru dari sekolah lain.

\section{Sikap Terhadap Anak Didik}

Dalam kode etik guru Indonesia disebutkan bahwa guru berbakti membimbing peserta didik untuk membentuk manusia Indonesia seutuhnya berjiwa Pancasila. Dasar ini mengandung beberapa prinsip yang harus dipahami seorang guru dalam menjalankan tugasnya sehari-hari, yakni: tujuan pendidikan nasional, prinsip membimbing, dan prinsip pembentukan manusia indonesia yang seutuhnya.

Tujuan pendidikan nasional sesuai dengan UU. No. 2/1989 yaitu membentuk manusia indonesia seutuhnya berjiwa Pancasila. Prinsip yang lain adalah membimbing peserta didik bukan mengajar, atau mendidik saja. Pengertian 
membimbing seperti yang dikemukakan oleh Ki Hajar Dewantara yaitu ing ngarso sung tulodo, ing madyo mangun karso, dan tut wuri handayani. Kalimat ini mengindikasikan bahwa pendidikan harus memberi contoh, harus dapat memberikan pengaruh, dan harus dapat mengendalikan peserta didik.

Prinsip manusia seutuhnya dalam kode etik ini memandang manusia sebagai kesatuan yang bulat dan utuh, baiki jasmani maupun rohani, tidak hanya berilmu tinggi tetapi juga bermoral tinggi pula. Dalam hal mendidik guru tidak hanya mengutamakan aspek intelektual saja, tetapi juga harus memperhatikan perkembangan seluruh pribadi peserta didik, baik jasmani, rohani, sosial, maupun lainnya sesuai dengan hakikat pendidikan.

\section{Sikap tempat kerja}

Untuk menyukseskan proses pembelajaran guru harus bisa menciptakan suasana kerja yang baik, dalam hal ini adalah suasana sekolah. Dalam kode etik dituliskan bahwa guru menciptakan suasana sekolah sebaik-baiknya yang menunjang berhasilnya proses belajar mengajar. Oleh sebab itu, guru harus aktif mengusahakan suasana baik itu dengan berbagai cara, baik dengan penggunaan metode yang sesuai, maupun dengan penyediaan alat belajar yang cukup, serta pengaturan organisasi kelas yang mantap, ataupun pendekatan lain yang diperlukan.

Selain itu untuk mencapai keberhasilan proses pembelajaran guru juga harus mampu menciptakan hubungan yang harmonis antar sesama perangkat sekolah, orang tua siswa, dan juga masyarakat. Hal ini dapat diwujudkan dengan mengundang orang tua sewaktu pengambilan rapor, membentuk BP3 dan lain-lain.

\section{Sikap Terhadap Pemimpin}

Sebagai salah seorang anggota organisasi, baik organisasi guru maupun yang lebih besar, guru akan selalu berada dalalm bimbingan dan pengawasan pihak atasan. Dari organisasi guru, ada strata kepemimpinan mulai dari cabang, daerah, sampai ke pusat. Begitu juga sebagai anggota keluarga besar depdikbud, ada pembagian pengawasan mulai dari kepala sekolah, kakandep, dan seterusnya samapai kementrian pendidikan dan kebudayaan. Kerja sama juga dapat diberikan dalam bentuk ususlan dan kritik yang membangun demi pencapaian tujuan yang telah digariskan bersama dan kemajuan organisasi. Oleh karena itu, dapat disimpulkan sikap seorang guru terhadap pemimpin harus positif dan loyal terhadap pimpinan.

\section{Sikap Terhadap Pekerjaan}

Dalam UU No. 14 Tahun 2005 pasal 7 ayat 1, tentang guru dan dosen merupakan bidang pekerjaan khusus yang dilaksanakan berdasarkan prinsip sebagai berikut: (a) Memiliki bakat, minat, panggilan jiwa, dan idealism, (b) Memiliki komitmen untuk meningkatkan mutu pendidikan, keimanan, ketakwaan, dan akhlak mulia. 
Hal ini berarti seorang guru sebagai pendidik harus benar-benar berkomitmen dalam memajukan pendidikan. Guru harus mampu melaksanakan tugasnya dan melayani peserta didik dengan baik. Agar dapat memberikan layanan yang memuaskan masyarakat. Guru harus selalu dapat menyesuaikan kemampuan dengan keinginan masyarakat, dalam hal ini peserta didik dan para orang tuanya. Keinginan dan permintaan ini selalu berkembang sesuai dengan perkembangan masyarakat yang biasanya dipengaruhi oleh perkembangan ilmu dan teknologi. Oleh karena itu, guru selalu dituntut untuk secara terus menerus meningkatkan dan mengembangkan pengetahuan dan keterampilannya.

\section{Kinerja Profesional Guru}

Sebagaimana penjelasan Undang-undang Republik Indonesia No. 14 Tahun 2005 tentang Guru dan Dosen: "guru adalah pendidik professional dengan tugas utama mendidik, mengajar, membimbing, mengarahkan, melatih, menilia dan mengevaluasi peserta didik pada pendidikan usia dini, pendidikan dasar, dan pendidikan menengah". Dalam Undang-undang No. 14 Tahun 2005 dijelaskan bahwa: "Guru mempunyai kedudukan sebagai teaga profesional pada jenjang pendidikan usia dini, pendidikan dasar, dan pendidikan menengah, pada jalur pendidikan formal yang diangkat sesuai dengan peraturan perundang-undangan. ${ }^{19}$

Selanjutnya kinerja profesional guru tidak hanya ditunjukan oleh pencapaian hasil kerja, akan tetapi juga ditentukan oleh perilaku dalam bekerja. Lembaga Administrasi Negara menyebut kinerja sebagai; "gambaran tentang singkat pencapaian pelaksanaan suatu kegiatan dalam mewujudkan sasaran". ${ }^{20}$ Kriteria kinerja guru ini diterjemahkan kepada ketentuan yang berlaku bagi PNS. Di dalam himpunan peraturan perundang-undangan tentang kepegawaian tahun 1982 yang diterbitkan oleh Depdikbud, kriteria kinerja guru PNS terdiri atas kesetiaan, prestasi kerja, tanggung jawab, ketaatan, kejujuran, dan kerja sama.

Kinerja guru juga dapat ditunjukan dari seberapa besar kompetensi-kompetensi yang dipersyaratkan dipenuhi. "Kompetensi tersebut meliputi kompetensi pedagogic, kompetensi kepribadian, kompetemsi sosial dan kompetensi professional. ${ }^{21}$ Sementara kinerja professional guru dapat terukur dengan jelas, dalam pembelajaran yang diperlihatkannya dari prestasi belajar peserta didik. Kinerja guru yang baik akan menghasilkan prestasi belajar peserta didik yang baik. Selanjutnya, "kinerja yang baik terlihat dari hasil yang diperoleh dari penilaian prestasi peserta didik".22

${ }_{19}$ Undang-undang RI. Nomor 14 Tahun 2005 Tentang Guru dan Dosen Pasal 2.

${ }^{20}$ Lembaga Administrasi Negara RI. Kinerja Aparatur Negara (Jakarta: LAN, 1993), 3.

${ }^{21}$ Lihat kembali Dalam Undang-undang Republik Indonesia Nomor 14 Tahun 2005 tentang Guru dan Dosen

22 N. S. Glasman, Evaluated-Based Leadership: School Administration in Contemporary Perspective (New York: State University of New York Press, 1986), 12. 
Di Indonesia, beberapa profesi masih pada taraf sedang berkembang termasuk profesi pendidik. Dalam praktek di lapangan, tidak semua okupasi didukung dengan kemampuan profesi, karena kondisi pasar tenaga kerja, belum dirumuskannya standar profesi, lemahnya organisasi dalam mengontrol pengisian okupasi, dan penerapan pengetahuan dan keterampilan yang lebih dikontrol oleh profesi lain. Kondisi semacam ini akan semakin berbahaya apabila dibiarkan karena tidak ada kepastian kemampuan minimal yang harus dipenuhi dalam mengisi okupasi, jeleknya layanan publik, dan biasanya cenderung berdampak kepada penyalahgunaan kewenangan. Menurut Saudagar dan Idrus suatu jabatan dapat termasuk kategori profesi apabila memenuhi setidak-tidaknya lima syarat, yaitu sebagai berikut.

1) Didasarkan atas sosok ilmu pengetahuan teoritik (body of theoretical knowledge) yang disepakati bersama.

2) Komitmen untuk menerapkan pengetahuan dan keterampilannya dalam praktek secara otonom dan berkekuatan monopoli.

3) Adanya kode etik profesi sebagai instrumen untuk memonitor tingkat ketaatan anggotanya dan sistem sanksi yang diperlukan.

4) Adanya organisasi profesi yang mengembangkan, menjaga, dan melindungi profesi.

5) Sistem sertifikasi bagi individu yang memiliki pengetahuan dan keterampilan untuk dapat menjalankan profesi tersebut.

Menurut Mulyasa ${ }^{23}$ faktor-faktor yang mempengaruhi kinerja profesional guru antara lain:

1) Sikap mental berupa motivasi, disiplin dan etika kerja.

2) Tingkat pendidikan, pada umumnya orang yang mempunyai pendidikan lebih tinggi akan mempunyai wawasan yang lebih luas.

3) Keterampilan, makin terampil tenaga kependidikan akan lebih mampu bekerja sama serta mengguinakan fasilitas dengan baik.

4) Manajemen atau gaya kepemimpinan kepala sekolah, artikan dengan hal yang berkaitan dengan sistem yang diterapkan oleh pimpinan untuk mengelola dan memimpin serta mengendalikan tenaga pendidikan

5) Hubungan industrial, menciptakan ketenangan kerja dan memberikan motivasi kerja, menciptakan hubungan kerja yang serasi dan dinamis dalam bekerja dan meningkatkan harkat dan martabat tenaga kependidikan sehingga mendorong mewujudkan jiwa yang ber dedikasi dalam upaya peningkatan kinerjanya

6) Tingkat penghasilan atau gaji yang memadai, ini dapat menimbulkan konsentrasi kerja dan kemampuan yang dimiliki dapat dimanfaatkan untuk meningkatkan kinerjanya.

7) Kesehatan, akan meningkatkan semangat kerja.

${ }^{23}$ E. Mulyasa, Standar Kompetensi dan Sertifikasi Guru, 140. 
8) Jaminan sosial yang diberikan dinas pendidikan kepada tenaga pendidikan, dimaksudkan untuk meningkatkan pengabdian dan semangat kerjanya.

9) Lingkungan sosial dan suasana kerja yang baik, ini akan mendorong tenaga kerja kependidikan dengan senang bekerja dan meningkatkan tanggung jawabnya untuk melekukan pekerjaan yang lebih baik.

10) Kualitas sarana pembelajaran, akan berpengaruh pada peningkatan kinerjanya.

11) Teknologi yang dipakai secara tepet akan mempercepat penyelesaian proses pendidikan, menghasilkan jumlah lulusan yang berkualitas serta memperkecil pemborosan.

12) Kesempatan berprestasi dapat menimbulkan dorongan psikologis untuk meningkatkan dedikasi serta pemanfaatan potensi yang dimiliki dalam meningkatkan kinerjanya.

\section{Pengembangan Sikap Profesionalisme Guru melalui Pendidikan dan Pelatihan}

Sebagaimana uraian yang telah dijelaskan di atas menjadi seorang guru bukanlah pekerjaan yang mudah, seperti yang dibayangkan sebagian orang, dengan bermodal penguasaan materi dan menyampaikannya kepada siswa dianggap sudah cukup, hal ini belumlah dapat dikategorikan sebagai guru yang memiliki pekerjaan profesional, karena guru yang profesional, mereka harus memiliki berbagai keterampilan, kemampuan khusus, mencintai pekerjaan, menjaga kode etik guru, dan lain sebagainya.

Sebagaimana studi lapangan yang diperoleh berdasarkan pengamatan dan wawancara pengembangan sikap profesionalisme guru di MTs Negeri 1 Serang diperoleh data bahwa sikap profesionalisme guru madrasah perlu dilakukan oleh Kementerian Agama baik daerah, propinsi maupun pusat dengan mengikuti beberapa agenda kegiatan yaitu Musyawarah Guru Mata Pelajaran (MGMP), Diklat di tempat kerja, pelatihan jarak jauh, Kelompok Kerja Madrasah (KKM), penyusunan buku ajar dan LKS serta lainnya yang dapat menunjang pada peningkatan profesionalitas guru.

Salah satu narasumber yang pertama memberikan argumennya adalah Hajiyah selaku kepala madrasah, menurut beliau proses pengembangan sikap profesionalisme guru di MTs Negeri 1 Serang tidak jauh berbeda dengan madrasah lainnya yaitu lebih mengedepankan sharing untuk mengetahui kekurangan dan kekuatan dalam mengembangkan sikap profesionalisme guru. Masih Hajiyah adapun untuk meningkatkan kinerja guru selain dilihat dari proses pembelajaran baik dilakukan di dalam kelas maupun di luar kelas di samping itu guru dituntut mengerjakan kegiatan-kegiatan lainnya berkaitan dengan kinerja guru, seperti mengerjakan administrasi sekolah dan administrasi pembelajaran, melaksanakan bimbingan dan layanan pada para siswa, serta melaksanakan penilaian. ${ }^{24}$

24 Hajiyah, Pengembangan Sikap Profesionalisme Guru dan Kinerja Guru MTsN 1 Serang. Wawancara Kepala Madrasah, Serang: MTsN 1 Serang, 18 Februari 2020. 
Kemudian hasil wawancara yang diperoleh dari Kepala Madrasah diperkuat kembali oleh Lia Hastuti Wakil Kepala Madrasah bidang Kurikulum, lanjut Lia pengembangan profesionalisme guru di MTs Negeri 1 Serang cukup berjalan dengan baik, hal ini sudah dilakukan sebagaimana mestinya. Kegiatan ini dilakukan sebagai upaya pengembangan sikap profesionalisme guru di MTs Negeri 1 Serang adalah melalui Pendidikan dan pelatihan (Diklat) MGMP, seminar dan workshop baik yang diadakan oleh Kementerian Agama melalui Forum Komunikasi Kepala Madrasah (FK2M) maupun internal sendiri melalui kelompok kerja madrasah (KKM). ${ }^{25}$

Sementara hasil wawancara dengan salah satu guru senior Bapak Ubay menjelaskan di samping untuk meningkatkan profesionalisme guru melalui pendidikan dan latihan sebagai bentuk program yang harus dilakukan, disamping itu tidak kalah pentingnya untuk menghasilkan pendidikan dan pembelajaran yang berkualitas maka keberadaan madrasah harus didukung oleh keberadaan pendidik yang profesional. Karena pendidik merupakan kunci pokok utama bagi keberhasilan pelaksanaan peningkatan mutu pendidikan. Untuk itu profesionalisme pendidik harus ditingkatkan dan dikembangkan. Pendidik dan tenaga kependidikan merupakan seorang yang profesional yang menuntut adanya suatu kecakapan atau keterampilan. Pengembangan sikap profesionalisme guru merupakan kegiatan meningkatkan kemampuan guru dalam proses pembelajaran secara efektif dan efisien. Jadi untuk profesionalisme guru tahapannya harus S1, maka di MTs Negeri 1 Serang dilihat dari kualifikasi pendidikan 100\% sudah S1 sebagian dari itu berjenjang S2, dan terdapat guru yang melanjutkan S2 melalui program beasiswa dari pemerintah Kementerian Agama RI, disamping itu ada beberapa guru yang berprestasi atau guru teladan tingkat propinsi Banten. ${ }^{26}$

Sementara menurut salah satu informan mengenai program pelatihan bagi guru akan lebih efektif jika dilakukan di dalam sekolah hal ini dikarenakan lebih baik dan lebih efisiensi waktu dan tidak memerlukan biaya transportasi lagi. Akan tetapi jika program pelatihan dilakukan di luar sekolah atau hanya dalam bentuk menghadiri acara pelatihan dari sekolah lain justru yang dikirimkan adalah guru yang memang sudah memiliki kuaifikasi sehingga pakan lebih paham, kemudian hasil dari pendidikan dan pelatihan dapat ditularkan pada guru-guru yang lain. Alternatif lain justru yang dikirimkan adalah guru yang belum memiliki kualifikasi sehingga akan dapat berkembang menjadi lebih baik. Dari sumber yang ada hemat penulis sendiri memberikan arahan dan penjelasan sebaiknya dalam program pelatihan ini pihak sekolah/madrasah lebih menekankan pada guru yang belum memiliki kemampuan dan sering mengadakan pelatihan disekolah meskipun hanya pelatihan dasar. Apabila terkendala oleh biaya maka pihak madrasah dapat mengambil alternatif berupa tutor/pemateri yang memberikan pelatihan adalah guru yang sudah mampu

25 Lia Hastuti, Pengembangan Sikap Profesionalisme Guru dan Kinerja Guru MTsN 1 Serang. Wawancara Wakaur Kurikulum, Serang: MTsN 1 Serang, 19 Februari 2020

${ }^{26}$ Ubay, Pengembangan Sikap Profesionalisme Guru dan Kinerja Guru MTsN 1 Serang. Wawancara dengan Guru, Serang: MTsN 1 Serang, 21 Februari 2020. 
untuk mengajari guru lain. Di samping itu harus adanya regulasi atau pergantian tidak hanya salah satu guru saja yang sering diikutsertakan dan pendidikan dan pelatihan sehingga semuanya dapat merasakan, dan terjadinya keseimbangan dalam mengembangkan sikap profesionalisme guru melalui pendidikan dan pelatihan ini.

Sebagai penguat di atas Mulyasa sendiri memberikan penjelasan mengenai pengembangan sikap profesionalisme guru, masih Mulyasa untuk menjadi guru yang yang professional setidaknya dituntut harus memiliki minimal lima hal sebagai berikut: (a) Mempunyai komitmen pada peserta didik dan proses belajarnya, (b) Menguasai secara mendalam bahan/ mata pelajaran yang diajarkan serta cara mengajarnya kepada peserta didik, (c) Bertanggung jawab memantau hasil belajar peserta didik melalui berbagai berbagai cara evaluasi, (d) Mampu berfikir sistematis tentang apa yang dilakukannya dan belajar dari pengalamannya, (e) Seyogyanya merupakan bagian dari masyarakat belajar dalam lingkungan profesinya. ${ }^{27}$

\section{Upaya Pengembangan Sikap Profesional Guru Melalui Peningkatan Kinerja Guru}

Peningkatan kinerja profesionalisme guru pada akhirnya berpeluang dan ditentukan oleh para guru. Upaya apa sajakah yang harus dilakukan guru untuk meningkatkan kinerja profesionalismenya? dari sekian banyaknya upaya dalam meningkatkan kinerja profesional guru pemerintah sering melakukan berbagai upaya peningkatan kualitas guru, antara lain melalui pelatihan, seminar, dan lokakarya, bahkan melalui pendidikan formal, dengan menyekolahkan guru pada tingkat yang lebih tinggi. Walaupun demikian pada pelaksanaannya masih jauh dari harapan.

Kaitannya dengan pengembangan sikap profesionalitas guru dalam meningkatkan kinerja guru dalam hal ini guru yang memiliki kemampuan serta profesionalitas akan memberikan hasil yang maksimal serta dapat meningkatkan prestasi sekolah. Dalam kegiatan pembinaan dan pengembangan profesionalitas guru terdapat beberapa program antara lain: (1) Program peningatan kualifikasi pendidikan guru, (2) Program penyetaraan dan sertifikasi, (3) Program pelatihan integritas berbasis kompetensi, (4) Program supervisi pendidikan, (5) Program pemberdayaan MGMP (Musyawarah Guru Mata Pelajaran), (6) Melakukan penelitian

Dari beberapa indikator di atas, dapat dideskripsikan berdasarkan hasil wawancara, berikut dengan dokumentasi mengenai pengembangan sikap profesionalisme guru melalui kinerja guru di MTs Negeri 1 Serang, baik dengan kepala madrasah, wakil kepala bidang kurikulum dan salah satu guru pengampu mata pelajaran fiqih yang tersertifikasi adalah sebagai berikut:

Berdasarkan wawancara dengan kepala madrasah, MTs Negeri 1 Serang memiliki 50 tenaga pengajar/guru dari jumlah tersebut terdapat kurang lebih sejumlah 38 dewan guru yang sudah tersertifikasi, dengan demikian kualifikasi tenaga pendidik menunjang proses pembelajaran di MTS Negeri 1 Serang. Meskipun demikian, kemampuan mengajar guru sudah memenuhi kualifikasi tertentu akan 
tetapi masih terbatas sehingga perlu adanya kegiatan pengembangan sikap profesionalismes guru guna memperdalam wawasan serta kemampuan sehingga kinerja dalam pembelajaran semakin baik. Terlebih untuk guru yang belum tersertifikasi diharapkan dapat meningkatkan kualifikasinya sehingga akan memberikan kontribusi keilmuan dan meningkatkan kinerja guru dan prestasi sekolah. ${ }^{28}$

Sementara Wakil kepala madrasah bidang kurikulum MTS Negeri 1 Serang Lia Hastuti memberikan pernyataannya terkait dengan pengembangan sikap profesionalisme guru bisa melalui pembinaan dan pelatihan sebagaimana telah dijelaskan di atas. Masih Lia kualifikasi tenaga pendidik adalah merupakan syarat pendidik karena para dewan guru sudah memiliki kemampuan dan keterampilan yang lebih dalam meningkatkan kompetensinya. Pembinaan dan pengembangan profesionalitas guru sebagai tenaga pendidik adalah pemenuhan kebutuhan utama yang harus dimiliki oleh guru. ${ }^{29}$ Kebutuhan yang harus dimiliki guru agar menjadi profesional dapat dilakukan melalui kegiatan-kegiatan yang berkesinambungan sesuai dengan kebutuhan yang diinginkan kemampuan dan keprofesionalan yang dimiliki guru memang harus ditingkatkan dengan melakukan program pembinaan dan pengembangan profesionalitas guru seiring dengan terus berkembangnya modernisasi dan informasi saat ini. Jika melihat kemampuan yang seharusnya dimiliki oleh seorang guru sebenarnya guru yang sudah menempuh pendidikan S1, tentu harus berkeinginan untuk melanjutkan jenjang pendidikannya pada program pascasarjana sebagai modal utama dalam mengembangkan sikap profesionalisme guru dalam meningkakan kinerja guru. Di samping itu merupakan amanat yang sesuai dengan undang-undang keguruan supaya dapat mengembangkan potensi yang ada pada diri guru

Berdasarkan pengamatan dan observasi serta wawancara di atas, hemat penulis sendiri memberikan asumsi bahwa kendala utama yang dihadapi guru yang belum memiliki kualifikasi adalah faktor biaya dan waktu. Pihak madrasah sebenarnya telah memberikan dorongan, arahan, dan motivasi supaya guru yang belum memiliki kualifikasi dapat mengembangkan profesionalitasnya. Dalam hal ini menurut penulis bahwa pihak sekolah sudah sangat berupaya guna meningkatkan program kualifikasi guru.

Sementara hasil wawancara dengan Bapak Ubay selaku guru dan menjabat wakil kepala bidang Humas menjelaskan mengenai upaya yang dilakukan dalam mengembangkan sikap profesionalisme guru dalam meningkatkan kinerjanya adalah dengan kegiatan supervisi pendidikan yang dilakukan oleh pihak kepala madrasah sebagai upaya realisasi pendidikan yang lebih baik lagi. Selain itu, pelaksanaan supervisi yang dilakukan oleh madrasah sampai dengan saat ini dapat dikatakan

28 Hajiyah, Pengembangan Sikap Profesionalisme Guru dan Kinerja Guru MTsN 1 Serang. Wawancara Kepala Madrasah, Serang: MTsN 1 Serang, 18 Februari 2020.

29 Lia Hastuti, Pengembangan Sikap Profesionalisme Guru dan Kinerja Guru MTsN 1 Serang. Wawancara Wakaur Kurikulum, Serang: MTsN 1 Serang, 19 Februari 2020 
telah cukup memenuhi hal yang harus dilakukan. Kegiatan supervisi pendidikan tidak hanya dilakukan oleh kepala, akan tetapi juga dilakukan oleh guru yang telah profesional untuk memberikan pengarahan kepada guru baru yang belum memiliki kemampuan secara baik. Tujuan dari adanya supervisi pendidikan adalah untuk memperbaiki guru dalam kegiatan belajar mengajar agar tercapai kualitas belajar mengajar sesuai dengan apa yang diharapkan oleh semua pihak dalam sebuah institusi pendidikan. Pihak madrasah memiliki otoritas penuh tentang pelaksanaan supervisi pendidikan dengan tujuan untuk mengoptimalkan kemampuan dan kinerja guru supaya menjadi lebih baik dan lebih profesional. ${ }^{30}$

Dari beberapa pernyataan di atas Presiden RI Ke-6, Susilo Bambang Yudhoyono mencanangkan guru sebagai tenaga profesi pada tanggal 2 Desember 2004. Melalui pencanangan ini diharapkan status sosial guru akan meningkat secara signifikan dan tidak lagi hanya di lirik oleh mereka yang menganggap profesi guru sebagai profesi alternatif mencari kerja. Eksistensi guru tersebut dikukuhkan melalui UU No. 14 tahun 2005 tentang Guru dan Dosen (UUGD) yang ditandatangani Presiden RI pada tanggal 30 Desember 2005. Karena Profesionalisme kependidikan merupakan syarat utama mewujudkan pendidikan bermutu di tanah air. Hal inilah yang melatarbelakangi pemerintah mengupayakan langkah-langkah strategis untuk meningkatkan profesionalitas guru-guru di masyarakat Indonesia. Begitulah ungkapan Presiden ke-6 RI menyadari begitu pentingnya peran guru. ${ }^{31}$

Sementara Undang-undang guru dan dosen di atas ini sangat dibutuhkan untuk melengkapi Undang-Undang Nomor 20 Tahun 2003 tentang Sistem Pendidikan Nasional. Pasal 39 Ayat (2) Undang-Undang Nomor 20 Tahun 2003 tentang Sistem Pendidikan Nasional menyatakan bahwa pendidik merupakan tenaga profesional. Kedudukan guru dan dosen sebagai tenaga profesional bertujuan untuk melaksanakan sistem pendidikan nasional dan mewujudkan tujuan pendidikan nasional, yaitu berkembangnya potensi peserta didik agar menjadi manusia yang beriman dan bertakwa kepada Tuhan Yang Maha Esa, berakhlak mulia, sehat, berilmu, cakap, kreatif, mandiri, serta menjadi warga negara yang demokratis dan bertanggung jawab.

Syaiful Bhari Djamarah memberikan batasan guru harus selalu berusaha memperbaiki untuk melakukan hal-hal sebagai berikut: Pertama, memahami tuntutan standar profesi yang ada, Kedua mencapai kualifikasi dan kompetensi yang dipersyaratkan, Ketiga, membangun hubungan kesejawatan yang baik dan luas termasuk lewat organisasi profesi, Keempat, mengembangkan etis kerja atau budaya kerja yang mengutamakan pelayanan bermutu tinggi kepada konstituen, kelima,

${ }^{30}$ Ubay, Pengembangan Sikap Profesionalisme Guru dan Kinerja Guru MTsN 1 Serang. Wawancara dengan Guru, Serang: MTsN 1 Serang, 21 Februari 2020

31 Lihat Juga, Alma Buchari, Guru Profesional Menguasai Metode dan Terampil Mengajar (Bandung: Alfabeta, 2009), 124. 
mengadopsi teknologi komunikasi dan informasi mutakhir agar senantiasa tidak ketinggalan dalam kemampuannya mengelola pembelajaran. ${ }^{32}$

Berkaitan dengan pernyataan Djamarah tersebut, jelaslah bahwa guru professional tidak hanya dituntut untuk menguasai bidang ilmu, bahan ajar, metode pembelajaran, memotivasi peserta didik, memiliki keterampilan yang tinggi dan wawasan yang luas terhadap dunia pendidikan, tetapi juga harus memiliki pemahaman yang mendalam tentang hakikat manusia, dan masyarakat. Hakikathakikat ini akan melandasi pola pikir dan budaya kerja guru, serta loyalitas terhadap profesi pendidikan.

Upaya peningkatan kualitas guru tersebut didasarkan pada terdapatnya kelemahan-kelemahan yang dialami oleh guru. Faktor utama yang menunjukkan lemahnya kinerja guru dalam melaksanakan pembelajaran, sebagaimana yang dikemukakan oleh Mulyasa sehubungan dengan: Tujuh indikator yang menunjukkan lemahnya kinerja guru dalam melaksanakan tugas utama mengajar (teaching), (a) rendahnya pemahaman tentang strategi pembelajaran, (b) kurang kemahiran dalam mengelola kelas, (c) rendahnya kemampuan melakukan dan memanfaatkan penelitian tindakan kelas, (d) rendahnya motivasi berprestasi, (e) kurang disiplin, (f ) rendahnya komitmen profesi, $(\mathrm{g})$ serta rendahnyya kemampuan manajemen waktu. ${ }^{33}$

Permasalahan rendahnya kualitas guru seperti yang dipaparkan di atas langsung atau tidak langsung berkaitan dengan profesionalisme yang masih belum memadai, sehingga perlu diselesaikan secara komprehensif menyangkut semua aspek terkait kesejahteraan, kualifikasi, pembinaan, pelindungan profesi, dan administrasinya. Dalam hal ini, menunjukkan bahwa profesionalisme guru di Indonesia masih sangat rendah, dan secara makro merupakan penyebab rendahnya mutu pendidikan nasional secara keseluruhan.

\section{D.PENUTUP}

Setelah penulis mengadakan penelitian berdasarkan obserbvasi dan wawancara tentang pengembangan sikap profesionalisme guru melalui kinerja guru di MTs Negeri 1 Serang, berdasarkan data yang diperoleh, sampai saat ini sudah dilakukan dengan baik dan sudah diupayakan oleh pihak madrasah untuk terus dapat berkembang. Akan tetapi ada beberapa program yang memang belum dapat dilaksanakan dengan optimal, tetapi semua itu bukan menjadi kendala pada aspekaspek yang dimaksud. Adapun program-program pengembangan sikap profesionalisme guru melalui kinerja guru baik melalui pendidikan dan pelatihan dengan mengikuti beberapa agenda kegiatan yaitu Musyawarah Guru Mata Pelajaran (MGMP), Diklat di tempat kerja, pelatihan jarak jauh, Kelompok Kerja Madrasah (KKM), penyusunan buku ajar dan LKS serta lainnya yang dapat

32 Syaiful Bahri Djamarah, Guru dan Anak Didik Dalam Interaksi Edukatif Suatu Pendekatan Teoretis Psikologis (Jakarta: Rineka, 2006), 22.

33 E. Mulyasa, Menjadi Guru Profesional, Menciptakan Pembelajaran Kreatif dan Menyenangkan (Bandung: Remaja Rosdakarya, 2008), 9. 
menunjang pada peningkatan profesionalitas guru. Hal ini bisa diikuti di lingkungan kementerian agama, Balai diklat Kemenag RI atau lembaga-lembaga lain yang menanungi kegiatan tersebut. Selain itu pihak madrasah melakukan pengiriman terhadap tenaga pendidik untuk mengikuti pendidikan dan pelatihan yang dilakukan oleh instansi-instansi terkait. Akan tetapi, guru yang dikirimkn justru guru yang memang telah memiliki sertifikasi guru, namun pelaksanaan di MTS Negeri 1 Serang jarang mengadakan pelatihan dikarenakan adanya keterbatasan waktu, tempat dan biaya.

Selain program di atas, pada program ini sebagian guru sudah memiliki kualifikasi sebagai guru yang profesional, hal ini terlihat hampir sebagian besar guru pada MTs Negeri 1 Serang sudah bersertifikat. Akan tetapi ada beberapa guru yang belum memiliki sertifikasi guru pada program ini sudah dilakukan guru dan pihak kepala madrasah selalu berupaya untuk para guru dapat secara keseluruhan melakukan program ini, hanya tinggal menunggu. Adapun kepala madrasah sampai dengan saat ini terus memberikan dorongan dan himbauan supaya guru dapat terus mengembangkan profesionalitas yang dimilikinya. 


\section{DAFTAR PUSTAKA}

Amri, Sofan. Peningkatan Mutu Pendidikan Sekolah Dasar dan Menengah dalam Teori Konsep dan Analisis. Jakarta: Prestasi Pustaka, 2013.

Aziz, A. Pendidikan Etika Sosial Berbasis Argumentasi Quranik. Andragogi: Jurnal Pendidikan Islam dan Manajemen Pendidikan Islam, 1(3) (2019): 466-489.

Buchari, Alma, Guru Profesional Menguasai Metode dan Terampil Mengajar. Bandung: Alfabeta, 2009.

Djamarah, Saiful Bahri, Guru dan Anak Didik dalam Interaksi Edukatif Suatu Pendekatan Teoretis Psikologis. Jakarta: Rineka, 2006.

Duli, David Thomas, Pengembangan Sikap Profesional." Jurnal Universitas Cendana 13. (2016).

Glasman, N. S. Evaluated-Based Leadership: School Administrattion in Contemporary Perspective. New York: State University of New York Press, 1986.

Hamalik, Oemar, Perencanaan Pengajaran Berdasarkan Pendekatan Sistem. Yogyakarta: Andi Offset. 2003.

Moleong. Metodologi Penelitian Kualitatif. Bandung: PT Remaja Rosdakarya, 1999.

Mulyana, E. Menjadi Guru Profesional, Menciptakan Pembelajaran Kreatif dan Menyenangkan. Bandung: Remaja Rosdakarya, 2008.

Mulyasa, E., Standar Kompetensi dan Sertifikasi Guru. Bandung: Remaja Rosdakarya. 2012.

Nata, Abuddin, Manajemen Pendidikan. Jakarta: Kencana Prenada Media Group, 2010. Nazir, Moh. Metode Penelitian. Jakarta: Ghalia Indo, 2009.

Peraturan Pemerintah Nomor 19 Tahun 2005.

Priansa, Donni, JuniKinerja dan Profesionalisme Guru. Bandung: Alfabeta, 2014.

Ramayulis, Profesi dan Etika Keguruan. Jakarta: Kalam Mulia, 2012.

RI, Lembaga Administrasi Negara. Kinerja Aparatir Negara. Jakarta: LAN, 1993.

Saihu, Pendidikan Pluralisme Agama: Kajian tentang Integrasi Budaya dan Agama dalam Menyelesaikan Konflik Sosial Kontemporer. Jurnal Indo-Islamika, 9(1), (2019): 67-90.

Saud, Udin Syaefudin, Pengembangan Prefesi Guru. Bandung: Alfabeta. 2010.

Soetjipto. Profesi Keguruan. Jakarta: Rineka Cipta, 2009.

Supardi, Kinerja Guru. Jakarta: PT Raja Grafindo Persada. 2013.

Trianto, Pengantar Penelitian Pendidikan bagi Pengembangan Profesi Pendidikan dan Tenaga Kependidikan. Jakarta: Kencana. 2011.

Undang-undang RI Nomor 14 Tahun 2015.

Widodo, Suparno Eko, Manajemen Pengembangan Sumber Daya Manusia. Yogyakarta: Pustaka Pelajar, 2015.

\section{Wawancara}

Hajiyah, interview by Aep Saepul Anwar. 2020. Pengembangan Sikap Profesionalisme Guru dan Kinerha Guru MTs N 1 Serang (Februari 18). 
Hastuti, Lia, interview by Aep Saepul Anwar. 2020. Pengembangan Sikap Profesionalisme Guru dan Kinerja Guru MTsN 1 Serang (Februari 19).

Ubay, interview by Aep Saepul Anwar. 2020. Pengembangan Sikap Profesionalisme Guru dan Kinerja Guru MTsN 1 Serang (Februari 21). 